\title{
ACUTE CORONARY SYNDROMES IN THE ELDERLY: IMPACT OF AGE ON DIAGNOSIS AND TERAPEUTIC MANAGEMENT
}

\author{
Pașc Priscilla ${ }^{1,2}$, Ioana Alexandra Coțe ${ }^{1}$, Mircea Ioachim Popescu ${ }^{1,2}$ \\ ${ }^{1}$ Clinical County Emergency Hospital of Oradea \\ ${ }^{2}$ Faculty of Medicine and Farmacy of Oradea, University of Oradea \\ Correspondent author: priscilla_pasc@yahoo.com
}

\begin{abstract}
Cardiovascular pathology in the elderly is a topic of particular interest because it is the main cause of morbidity and mortality in this segment of the population, but also because in the last century the population over 60 years (this is the arbitrary limit from which a person is considered to be elderly) has doubled and is estimated to increase 2-3 times during the first century of this millennium. With the aging of the population, the number of associated diseases increases, but also the complexity of treatment for these diseases and the cost of hospitalization. Ischemic coronary artery disease has an increased incidence in the elderly population.

Acute myocardial infarction (AMI) with ST segment elevation is manifested relatively frequently with atypical symptoms at onset - dyspnea, diaphoresis, nausea, confusion, epigastric pain, syncope. The influence of age on diagnosis and therapeutic management. There are no electrical changes in $40 \%$ of the elderly with acute myocardial infarction. Statistics show that $50 \%$ of patients addmited for AMI are elderly and $80 \%$ of acute myocardial infarction deaths occur in the elderly, due to both greater risk of post-treatment complications (eg left ventricular rupture after fibrinolysis) and general suboptimal treatment in the eldery, either due to age, comorbidities and atypical presentation delaying the diagnosis. Generally, outcomes of patients undergoing percutaneous coronary intervention are better compared to patients treated with fibrinolysis, the invasive strategy being thus preferred in these patients.
\end{abstract}

Key words: elderly, mortality, complexity of treatment, frailty.

\section{Rezumat}

Patologia cardiovasculară la vârstnici reprezintă o temă de interes deosebit având în vedere faptul că, pe de o parte aceasta reprezintă principala cauză de morbiditate şi mortalitate în acest segment de populaţie, dar şi faptul că, în ultimul secol, populaţia peste 60 de ani (aceasta fiind limita arbitrară de la care o persoană este considerată vârstnică) s-a dublat şi se estimează că va creşte de 2-3 ori în decursul primului secol al acestui mileniu.

O dată cu îmbătrânirea populaţiei creşte numărul bolilor asociate, dar totodată şi complexitatea tratamentului adresat acestor boli şi costul serviciilor de spitalizare.

Boala coronariană ischemică prezintă o incidenţă crescută în populaţia vârstnică. Infarctul miocardic acut (IMA) cu supradenivelare segment ST se manifestă relativ frecvent printr-un tablou clinic cu simptome atipice la debut - dispnee, diaforeză, greaţă, confuzie, durere 


\section{INTERNAL}

\section{General Reviews}

epigastrică, sincopă. Este de menţionat şi faptul că, la 40\% dintre vârsnicii cu infarct miocardic acut nu apar modificări electrice. Statisticile arată că 50\% dintre pacienţii care prezintă IMA sunt vârstnici şi 80\% dintre decesele post-infarct miocardic acut survin la vârstnici, acest fapt fiind datorat atât riscului mult mai mare de complicaţii posttratament (de exemplu ruptura ventriculului stâng după fibrinoliză), cât şi administrării în general de tratament suboptimal la vârsnici, fie din cauza vârstei, a comorbidităţilor, dar şi din cauza prezentării atipice care întârzie diagnosticul. În general, evoluţia pacienţilor vârsnici după revascularizare intervenţională este mai bună comparativ cu cea de după fibrinoliză, strategia invazivă fiind astfel de preferat la aceşti pacienţi.

Cuvinte cheie: vârstnici, mortalitate, complexitatea tratamentului, fragilitate.

\section{EPIDEMIOLOGY}

Elderly patients ( $>75$ years) represent a large percentage of patients addmited with acute coronary syndromes, and current trends regarding the incidence of myocardial infarction reveals a tendency towards elderly adults. The average age of presentation in the emergency service for the first acute coronary syndrome is 65 years old for men and 72 years old for women.

Approximately two-thirds of myocardial infarctions occur in patients over 65 years old and one-third in patients over 75 years old. However, the exact prevalence and incidence of SCA in elderly over 75 years old are unknown. Randomized clinical trials, on the other hand, included fewer elderly patients than they are in real life. Sixty percent of SCA hospitalizations occur in patients over the age of 65 , with most of the deaths related to myocardial infarction occurring in this population.

Large studies conducted only in this category of patients suggest that patients over the age of 75 represent $32 \%$ to $43 \%$ of NSTE-ACS cases and approximately $24 \%-28 \%$ of STEMI cases. In both STEMI and NSTE-ACS categories, advanced age is associated with increased mortality. Mortality is at least three times higher in patients over 85 years of age, compared to the age group under 65 years old. The mean survival time after a first $\mathrm{MI}$ is 3.2 years for men and women at the age $\geq 75$ years, while 9.3 years for males and 8.8 years for women aged between 65 and 74 years of age; 17.0 for men and 13.3 for women aged 55 to 64 . Each 10-year-old increase led to a $75 \%$ increase in hospital mortality in patients with ACS. Both the Global Registry of Acute Coronary Events (GRACE) and the UK Myocardial Ischemia National Audit Project 
database have shown that acute coronary syndromes in older adults are more likely to occur as NSTE-ACS instead of STEMI.

\section{AGING CHANGES IN THE HEART AND BLOOD VESSELS}

The elderly's heart is characterized by the physiological appearance of structural and functional changes. It increases the diameter of myocytes, increases collagen and amyloid deposits resulting in left ventricular hypertrophy, cardiac geometry changes, calcifications and valvular fibrosis occur, degenerative changes occur in the excitoconduct tissue and sympathetic vegetative nervous system. All of these structural changes also cause functional changes in the heart, with remodeling of left heart cavities by decreasing compliance and increasing their rigidity, decreased lusitrope function, decreased response to betaadrenergic stimuli. Age is not only an important risk factor for cardiovascular disease, it is also a negative prognostic factor for survival after cardiovascular events, complications of cardiovascular interventions and procedures and side effects of pharmacotherapy, especially of the antithrombotic therapies. In addition, older patients generally have a more complex cardiovascular disease, more comorbidities and, in general, a more atypical clinical presentation. There is a higher prevalence of high blood pressure, congestive heart failure (CHF), atrial fibrillation, cerebrovascular disease, anemia and renal insufficiency in elderly patients with ACS. Age also has important implications for the pharmacokinetics and pharmacodynamics of administered drugs.

\section{PHYSIOPATHOLOGY}

From the pathophysiological point of view, coronary atherosclerosis is the result of prolonged processes that intersect with general aging mechanisms. Characteristic for the elderly are far more extensive calcifications of the coronary arteries, with multivessels and left main trunk involvement.

The process of atherogenesis includes endothelial lesions, lipid particle deposition (fatty formation), localized cellular and inflammatory response (early atheroma) followed by progression of atheroma with formation and expansion of the necrotic core, the fibrous cap, and the increasing degree of instability of the atheroma plaque, interconnected with different degrees of thrombosis. The "open-artery" theory argues that thrombosis at the site of rupture, erosion, or cracking of the atherosclerotic plaque leads to STEMI or Non ST-ACS, depending on the degree and duration of the obstruction. The distinctive sign of ACS is the sudden imbalance between myocardial oxygen consumption and demand. This may be due to acute thrombosis and plaque rupture or increased need for oxygen under various pathological conditions (eg tachycardia, hypotension or anemia).

\section{ATYPICAL SYMPTOMS}

There may be more explanations for which older people have a more unfavorable outcomes after an ACS episode. While chest pain remains the most common presentation of ACS, elderly patients frequently experience atypical symptoms (without chest pain). In patients presenting without chest pain, the diagnosis of ACS is often missed or delayed, leading to unfavorable outcomes. In particular, chest pain, as a symptom of MI presentation, occurs only in $40 \%$ of patients over 85 years but is present in almost $80 \%$ of patients under the age of 65 years. Common symptoms in elderly patients with ACS include dyspnoea, diaphoresis, nausea, vomiting and syncope. In patients aged at least 85 years, an atypical presentation of myocardial infarction appears 


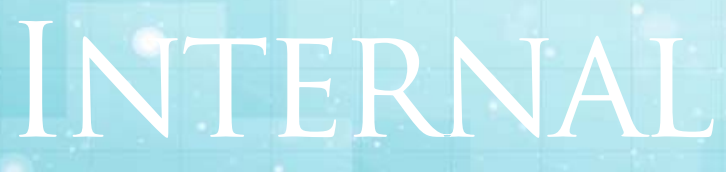

General Reviews

to be very common and the clinician should be prepared to diagnose an ACS in this age group of patients. Acute pulmonary edema is very common in the elderly patient with ACS. Increased arterial rigidity manifested by increased arterial pulse pressure and increased prevalence of coronary multivessels disease may explain why older patients with ACS are more likely to experience signs and symptoms of heart failure.

\section{RISK STRATIFICATION IN THE ELDERLY}

Generally, patients at high ischaemic risk, presenting with ACS, justify more aggressive therapeutic strategies, particularly antithrombotic, anticoagulant and miocardial revascularization strategies, to reduce the risk of major cardiovascular events (death, recurrent ischaemia / myocardial infarction). Prognostic factors that predict higher ischemic risk in score risk systems of acute coronary syndromes, such as the TIMI risk score, the GRACE score and the TIMI risk index, also predict a higher risk of bleeding when receiving aggressive therapies. Age is one of the most important predictors of risk in NSTEACS. Patients aged $\geq 75$ years have at least twice the mortality rate $\leq 75$ years. As predicted, all older adults with ACS (NSTE-ACS and STEMI) with elevated CTnl, with or without ECG changes, who are at increased risk and may benefit from aggressive therapy, are also at increased risk of bleeding. Frailty of the elderly, which shows increased vulnerability and physiological multiple organ dysfunction in elderly population, is a strong and independent predictor of increased mortality, longer hospital stay and increased risk of bleeding and morbidity in elderly patients with ACS. The multisystemic physiological decline of the elderly is also a predictor of poor therapeutic outcomes for these.

\section{POORER OUTCOMES IN THE ELDERY}

Pre-hospital delays prevent prompt treatment. Although they have a more severe coronary artery disease than younger patients in coronary angiography, elderly patients are more susceptible to conservative treatment and complications. In addition, the hemodynamic impact of infarct size may be more pronounced in the elderly due to reduced cardiac reserve.

Type 2 myocardial infarction resulting from increased myocardial oxygen demand is usually caused by comorbidities such as tachycardia, hypoxemia pneumonia, chronic pulmonary disease, and bleeding episodes. These comorbidities have to be recognized because they require treatment strategies different from those of type 1 myocardial infarction. Generally, elderly patients are more prone to ACS complications such as heart failure, atrioventricular disturbances, ventricular rupture and atrial fibrillation. Moreover, frailty and disability can complicate acute hospitalization as well as convalescence and rehabilitation. On the other hand, 
disability is not taken into account in clinically approved risk scores.

\section{THERAPEUTIC MANAGEMENT-GENERAL CONSIDERATIONS}

ACS treatment has evolved significantly over the last 40 years. Classically, ACS is caused by the thrombotic obstruction of an epicardial coronary artery. Thus, treatment focuses primarily on early coronary revascularization, supported by the use of antithrombotic therapy. Generally, the more aggressive use of invasive coronary procedures and antithrombotic drugs is associated with a lower risk of ischemic complications, but with a higher risk of bleeding complications. Research results have shown that elderly people have generally been treated less efficient. Probably, clinicians believe that the risk / benefit ratio of cardiac procedures is less favorable in the elderly. While increasing survival rates were not seen among elderly patients during the early days of coronary interventions,, more recent data showed that long term mortality after hospitalization of elderly patients with acute myocardial infarction decreased substantially over the last 15 years .

This improvement is probably mediated by the increased use of standard therapies; thus, applying treatment guidelines based on studies on a younger population can also bring benefits to the elderly. However, negative outcomes increase with age across the spectrum of ACS. Data from European registries of acute coronary syndromes show a substantial reduction in hospital mortality in all age groups, including the elderly, with STEMI and NSTE-ACS. The use of percutaneous coronary intervention $(\mathrm{PCl})$ and evidencebased pharmacology therapy has increased significantly for all age groups. Although elderly patients have continued to experience fewer coronary revascula-rizations than younger patients, it is noteworthy that more than half of all STEMI patients over 85 years of age have benefited from $\mathrm{PCl}$ and adherence to evidence-based pharmacotherapy on discharge was about $90 \%$.

The Italian study "Italian Elderly ACS" suggests that elderly patients with elevated troponin levels benefit from an early invasive approach. Data from the same study, in accordance with data from European national registries, suggested that coronary revascularization in elderly women was associated with a lower one year mortality compared to a conservative approach, without increasing the incidence of significant haemorrhages. The results of the "After Eighty" study support the use of an invasive strategy in patients over 80 years old. Despite an increased major bleeding risk in patients over 75 years of age, an early invasive routine strategy significantly improved outcomes in elderly patients with ACS. Data from the registry suggests that, for 15 years, the progressive transition from a conservative approach to a more invasive approach to elderly patients may contribute to reducing ACS spectrum mortality, regardless of age and gender. Consequently, the absolute benefit of early invasive therapies in the elderly appears to be higher than in younger patients due to their high mortality at baseline.

\section{PHARMACOTHERAPY}

The risk of adverse drug reaction has been reported to increase with the number of concomitant medications. With two competing drugs, there is a $13 \%$ risk for an adverse drug reaction, and the risk increases up to $38 \%$ for four drugs and $82 \%$ for seven or more prescribed drugs simultaneously. Drugs side effects are generally more common in elderly patients with ACS; therefore, particular attention should be paid to monitoring and reducing side effects, especially when initiating drug therapy. According to age, 


\section{INTERNAI}

General Reviews

internal organ function, muscle mass and volume of distribution, pharmacokinetics changes, the physician must meticulously adjust the dose of medication. As the bleeding risk increases with age, dose adjustments are particularly important when it comes to anticoagulant treatments.

The creatinine clearance is preferably calculated using the Cockcroft-Gault equation. Observational data has shown that patients with ACS often receive excessive doses of antithrombotic drugs. Factors associated with overdose include older age, female gender, renal insufficiency, low body weight, diabetes mellitus and cronic heart failure. Among patients who have recently suffered an acute coronary sindrome, it is known that a high dose regimen of statins provides greater protection against death or major cardiovascular events than a low or moderate dose regimen.

A subgroup analysis of the PROVE-IT-TIMI study (Pravastatin or Atorvastatin Assessment and Thrombolysis Therapy in myocardial infarction), including 634 elderly patients, suggested that a high dose statin regimen had a greater reduction in adverse events in the elderly. While randomized data are rare in patients over 75 years of age, an observational study has shown that early beta-blocker therapy was not used in $51 \%$ of patients over 65 years old who were hospitalized with an acute myocardial infarction, although they did not have a clear contraindication to this therapy. However, the same study showed that patients who received beta-blockers had a lower incidence of hospital death than patients who did not receive beta-blockers. Results from CRUSADE (Can Rapid Risk Stratification of Unstable Angina Patients Suppress Adverse Outcomes with Early Implementation of the American College of Cardiology / American Heart Association Guidelines) have shown that early hospital use of aspirin and beta-blockers was less likely in patients over 65 years and that heparin was significantly less used at the age of 85 years. The acute use of clopidogrel and glycoprotein IIb / IIla inhibitors was the most influenced by age. Only $30 \%$ of patients over 85 years of age received clopidogrel and only $12.8 \%$ received platelet glycoprotein $\mathrm{llb} /$ Illa inhibitors. The therapeutic plan at discharge was similar in young and old patients, with the exception that clopidogrel and statin therapy remained less commonly prescribed in elderly patients. While in-hospital mortality and complication rates increased with age, those who received many of the recommended drug therapies in patients with ACS had a lower mortality.

\section{MYOCARDIAL REVASCULARIZATION}

Most elderly patients are addmited with myocardial infarction without ST elevation, most likely due to the multivascular lesions, which causes an ischemic preconditioning and a significant development of collateral circulation. Less than $30 \%$ of addmited 
patients over 75 years of age are caused by STEMI. Although it is well established that coronary reperfusion is crucial within 12 hours from symptoms onset, in the Global Registry of Acute Coronary Events (GRACE), 30\% of patients with STEMI who presented in the emergency service 12 hours after the symptoms onset, did not receive reperfusion therapy.

Patients over 75 years old had the lowest percentage of myocardial revascularization. Current data support the use of reperfusion therapies, including fibrinolysis, even over the age of 85 years. The selection between fibrinolysis or $\mathrm{PCl}$ is largely determined by factors other than age, such as presentation time, distace to the cardiac catheterization room, comorbidity, and signs of cardiogenic shock. The safety and efficacy of reperfusion, especially of fibrinolytic therapy, in elderly people ( $\geq 85$ years) are not yet well established since the risks of intracranial bleeding and cardiac rupture increase with age. When considering revascularization option for the elderly, it is reasonable to choose coronary artery bypass surgery (CABG) than $\mathrm{PCl}$ in older patients with STE- ACS, especially those with diabetes or with multivascular complex disease. CABG may become the only option in certain clinical situations, such as a coronary anatomy that is not accessible to $\mathrm{PCl}$, failed $\mathrm{PCl}$ or the need for surgical repair of mechanical complications or concomitant valve disease. In a subgroup analysis of the Radial Versus Femoral Access for Coronary Intervention study, elderly patients who underwent cardiac catheterization had lower bleeding rates or complications, however elderly patients also had higher rates of radial catheterization compared to femoral catheterization.

\section{POST-ACS FOR OLDER PATIENTS}

Older adults are prone to complications. In the acute phase, these complications include: (1) complications related to ischemia (heart failure due to failure of the pump, pericarditis post-MI, arrhythmia (both ventricular arrhythmia and fibrillation, conduction abnormalities), mechanical complications caused by ischemia, muscle papillary VSD, rupture of the free wall); (2) procedural complications (access / hematoma bleeding, retroperitoneal bleeding, stroke, pericardial effusion); (3) bleeding due to antiplatelet therapy and anemia; (4) renal insufficiency; (5) hypotension due to excessive medication; (6) the adverse effects of new drugs. Post ACS, elderly patients have an increased risk of rehospitalization and death, both due to cardiovascular and non-cardiovascular etiologies.

There is an increased risk of mortality of $50 \%$ in every 10 -years age increase starting the age of 65 years. Elderly patients suffering from ACS are particularly vulnerable. Because comorbidities, polifarmacy impaired cognitive functions, a complex discharge treatment plan, involving patients and their families is essential and often challenging. Low compliance to a discharge care plan contributes to higher rates of ACS rehospitalization and to worse outcomes. The discharge care plan should include (1) detailed lists of medicines and instructions; (2) a clear monitoring agreement; (3) dietetic instructions; (4) physical activity instructions; (5) a plan for adverse effects of drugs and interventions; (6) cardiac rehabilitation.

\section{CONCLUSION}

As the population continues to get older, clinicians will face an increasing number of old and very old patients presenting with ACS. While treatement care needs to be individualized, age alone should never be the reason to stop potential life-saving procedures and interventions. Elderly patients have an increased risk of bleeding complications but also have the greatest risk for ischemic 


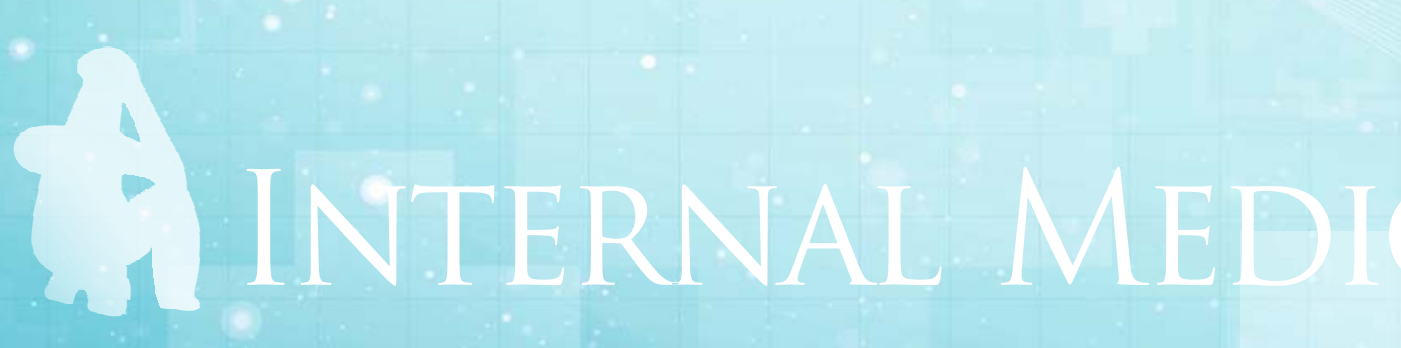

General Reviews

complications if they are pursuing less aggressive treatment strategies. Thus, clinicians are entrusted with a meticulous risk stratification for ischemic risk and bleeding risk, taking into account the assessment of frailty, quality of life, care objectives and individual preferences. Early invasive protocols appear to be equally feasible in the elderly as well as in the general population. To reduce the risk of bleeding and adverse side effects, it is imperative to correct the dose of pharmacotherapy to age-adjusted renal function and the volume of distribution.

\section{References}

1.Xuming Dai, Jan Busby-Whitehead, and Karen $P$ Alexander, Acute coronary syndrome in the older adults,J Geriatr Cardiol. 2016 Feb; 13(2): 101-108.

2. Niels Engberding and Nanette $K$. Wenge, Acute Coronary Syndromes in the Elderly, Version 1. F1000Res. 2017; 6: 1791

3.O'Gara PT, Kushner FG, Ascheim DD, et al. 2013 ACCF/AHA guideline for the management of ST-elevation myocardial infarction: executive summary: a report of the American College of Cardiology Foundation/American Heart Association Task Force on Practice Guidelines. J Am Coll Cardiol. 2013;61:485-510.

4.Lopes RD, Gharacholou SM, Holmes DN, et al. : Cumulative incidence of death and rehospitalization among the elderly in the first year after NSTEMI. Am J Med. 2015;128(6):582-90. 10.1016/j.amjmed.2014.12.032

5. Puymirat E, Aissaoui N, Cayla G, et al. Changes in OneYear Mortality in Elderly Patients Admitted with Acute Myocardial Infarction in Relation with Early Management.
Am J Med. 2017;130(5):555-63. 10.1016/j.amjmed. 2016.12.005

6. Gale CP, Cattle BA, Woolston A, et al. : Resolving inequalities in care? Reduced mortality in the elderly after acute coronary syndromes. The Myocardial Ischaemia National Audit Project 2003-2010. Eur Heart J. 2012;33(5):630-9. 10.1093/eurheartj/ehr381

7. De Carlo M, Morici N, Savonitto S, et al. : Sex-Related Outcomes in Elderly Patients Presenting With Non-STSegment Elevation Acute Coronary Syndrome: Insights From the Italian Elderly ACS Study. JACC CardiovasC Interv. 2015;8(6):791-6. 10.1016/j.jcin.2014.12.

8. Tegn $N$, Abdelnoor M, Aaberge L, et al. : Invasive versus conservative strategy in patients aged 80 years or older with non-ST-elevation myocardial infarction or unstable angina pectoris (After Eighty study): an open-label randomised controlled trial. Lancet. 2016;387(10023): 1057-65. 10.1016/S0140-6736(15)01166-6

9. De Luca L, Olivari $Z$, Bolognese $L$, et al. : A decade of changes in clinical characteristics and management of elderly patients with non-ST elevation myocardial infarction admitted in Italian cardiac care units. Open Heart. 2014;1(1):e000148. 10.1136/openhrt-2014-000148 10. Cantor WJ, Mehta SR, Yuan F, et al. : Radial versus femoral access for elderly patients with acute coronary syndrome undergoing coronary angiography and intervention: insights from the RIVAL trial. Am Heart J. 2015;170(5):880-6. 10.1016/j.ahj.2015.08.011

11.Cantor WJ, Mehta SR, Yuan F, et al. : Radial versus femoral access for elderly patients with acute coronary syndrome undergoing coronary angiography and intervention: insights from the RIVAL trial. Am Heart J. 2015;170(5):880-6. 10.1016/j.ahj.2015.08.011

12.. Frengley JD, Sansone GR, Alba A, et al. : Influence of age on rehabilitation outcomes and survival in post-acute inpatient cardiac rehabilitation. J Cardiopulm Rehabil Prev. 2011;31(4):230-8. 